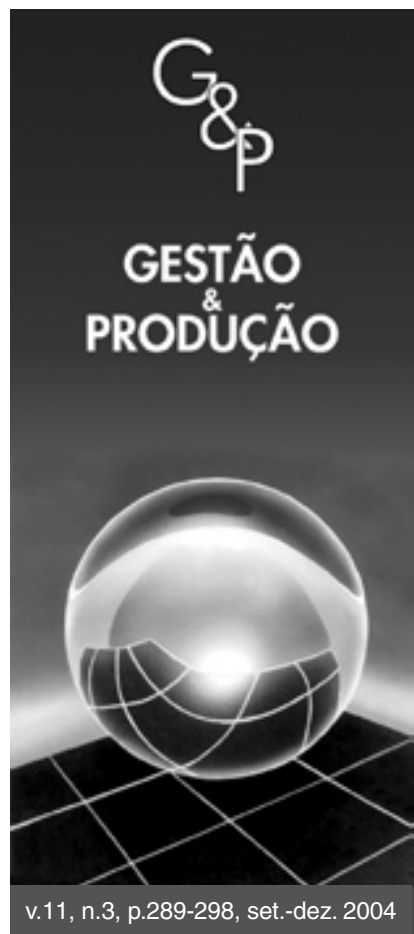

\title{
INVESTIGATION OF SUPPLIER/BUYER COORDINATION PERFORMANCE IN CHINESE COMPANIES
}

\author{
Chen Zhixiang \\ School of Business, Zhongshan (SunYat-Sen) University, \\ Guangzhou, 510275, P. R. of China \\ e-mail:mnsczx@zsu.edu.cn
}

Abstract

This paper discusses the performance of supplier/buyer coordination in supply chain systems in China based on data from a survey of that country's business sector. The survey indicates that the rapidly expanding economy has raised the awareness of an increasing number of Chinese firms to the importance of cooperating and coordinating with partners in supply chain management. However, although coordinated delivery, quality and responsiveness show an upward trend, such is not the case in information sharing and in cooperative efforts to reduce inventory and costs. Hence, many companies have yet to form close cooperative relationships with partners. This study may be useful for both Chinese and foreign companies, serving to underpin the development of new strategies for operating supply chains in the changing global economy.

Keywords: supplier/buyer relationships, coordination, agile supply chain.

\section{Introduction}

Supply chain management represents a new competitive strategy for the new century. In recent years, an increasing number of people have been attentive to the performance of supply chain management (Gunasekarn et al., 2001; Van Hoek et al., 2001; Ramdas and Spekman, 2000; Agarwal and Shankar, 2002; Chan and Qi, 2002; Beamon, 1999). Unlike other studies reported in the literature that focus on the overall operational performance of supply chains, this paper investigates the performance of supplier/buyer coordination based on data from a survey of China's business sector, exploring supplier/buyer relationships and proposing solutions aimed at improving supply chain management.

\section{Key performance indices for buyer- supplier coordination in supply chain systems}

A number of articles on supply chain management performance have been published in academic journals in recent years. In our vision, the most perfect framework for measuring the performance of supply chain management was proposed by Gunasekaran et al. (2001), who established a framework consisting of three level indices: (1) Strategic performance; (2) Tactical performance; and (3) Operational performance. Unfortunately, however, their paper lacks empirical data.

Van Hoek et al. (2001) measured supply chain agility based on four factors: (1) Sensitivity to the customer; (2) Virtual integration; (3) Process integration; (4) Network integration. Their research comprised a systematic theoretical analysis and an empirical investigation based on questionnaires, but did not include indices to quantity performance.

Ramdas and Spekman (2000) proposed the measurement of supply chain performance based on the variables of inventory, time, order fulfillment, quality, customer focus, and customer satisfaction. They measured performance for two types of supply chains, i.e., innovative sup- 
ply chains and functional supply chains.

Beamon (1999) stated that most traditional models for measuring performance used predominantly two distinct performance measurements: (1) cost; and (2) a combination of cost and customer responsiveness. This author proposed a new framework for selecting performance measurement systems for manufacturing supply chains: (1) Resource indices; (2) Output indices; and (3) Flexibility indices. Resource indices include cost, inventory, return on investment (ROI); output indices include sales, profit, fill rate, on-time deliveries, and backorder/stock out, customer response time, manufacturing lead-time, customer complaints and shipping errors; and flexibility indices include volume flexibility, delivery flexibility, mix flexibility, and new product flexibility.

Although the literature contains a number of researches on supply chain performance, most of them are based on the entire supply chain management system rather than on special supply chain strategy. Supplier/buyer coordination is a crucial operational strategy; however, although much attention has focused on its technology and method, performance measurements have not been studied empirically. Table 1 shows some critical performance dimensions for buyer-supplier coordination summarized from different authors' viewpoints.

Referring to other researchers' viewpoints combined with our own investigation into business practices in China, this paper establishes a set of key performance indices for buyer-supplier coordination in supply chains, as indicated in Table 2.

\section{Methodology}

Our investigation into the performance of supplier/ buyer coordination in Chinese companies was based on a survey we conducted from August 2002 to October 2003. Based on a questionnaire and on statistical data, we analyzed the performance of buyer-supplier coordination. The following section describes the questionnaire, the sampling method and our analysis of the collected data.

\subsection{Questionnaire design}

The questionnaire consisted of three sections:

(1) Basic company information, including ownership, type of industry, geographical distribution, variety and scale of purchased materials, organizational structure, etc;

(2) Measurement of buyer-supplier coordination performance. All the questions offered multiple choice answers, some of them qualitative, using descriptive words such as "good", "high", and others quantitative, using numbers or percentages such as "99\%" or "more than 3 years"; and

(3) Buyer-supplier coordination strategies. Similar to the performance measurement, questions regarding buyersupplier coordination strategies also involved multiple choice replies.

\subsection{Sampling and data analysis}

The first sampling began in August 2002, when 1420 questionnaires were mailed to companies in different geographical locations in China. At the same time, 100 questionnaires were dispatched directly to MBA students at our university (spot sampling). The first round of sampling yielded a very low response rate, so we reduced sampling by mail and increased spot sampling in the second round. To improve the representativeness of the spot sampling, we increased our spot sampling from 1 to 6 universities located in different parts of China. The institutions involved were Beijing University, a university in the north, Fudan University in the east, Huazhong University of Science \& Technology, a university in central China, and Zhongshan University in the south. Because these four regions are the fastest growing in China and because the aforementioned universities are well known and their MBA students are connected to companies in different regions of China, the spot sampling from the universities in these four regions basically reflects China's supply chain management trends. Table 3 shows the sample sizes resulting from the two sampling rounds.

An analysis of the data indicates that non-response bias

Table 1. Buyer-supplier coordination performance dimensions.

\begin{tabular}{ll}
\hline \multicolumn{1}{c}{ Performance dimension } & \multicolumn{1}{c}{ Researcher and time } \\
\hline Level and degree of information sharing & $\begin{array}{l}\text { Toni et al. (1994) } \\
\text { Mason-Jones and Towill (1999) } \\
\text { Gunasekaran et al. (2001) }\end{array}$ \\
\hline Buyer-supplier cost saving initiatives & $\begin{array}{l}\text { Thomas and Griffin (1996) } \\
\text { Gunasekaran et al. (2001) }\end{array}$ \\
\hline Extent of mutual cooperation leading to improved quality & Graham et al. (1994) \\
& Gunasekaran et al. (2001) \\
& Fabrizio et al. (2001) \\
\hline The extent and stage at which suppliers are involved & Toni et al. (1994) \\
& Gunasekaran et al. (2001) \\
\hline Extent of mutual assistance in problem solving efforts & Maloni and Benton (1997) \\
& Gunasekaran et al. (2001) \\
\hline
\end{tabular}


is insignificant between the two sampling rounds. Among the questionnaires returned, company ownership was distributed as follows: 79 state-owned companies (accounting for $37.4 \%$ ), 45 privately owned companies (accounting for $21.3 \%$ ), 40 Sino-foreign joint venture companies (accounting for 19.0\%), 42 foreign companies (19.9\%), and 5 companies with other types of ownership. The distribution of companies by type was: domestic appliances: $10 \%$, chemicals: $3 \%$, mechanical products: $18 \%$, automotive: $8 \%$, food: $5 \%$, telecommunications and IT: $8 \%$, pharmaceuticals: $5 \%$, metallurgy: $4 \%$.

\section{Analysis of overall results}

This section briefly discusses our findings according to the supplier/buyer coordination performance indices listed in Table 2.

\subsection{Operational performance}

According to Table 2, operational performance indices are divided into four dimensions: materials flow, information flow, cash flow and workflow performance.

\subsubsection{Materials flow coordination perfor- mance}

Several indices can be used to measure the performance of materials flow in supply chains. In our survey, we used five materials flow indices: (1) inventory turnover; (2) safety stock; (3) on time delivery; (4) lead time and related purchasing tendency; and (5) quality of materials.

\subsubsection{Inventory turnover}

As a general rule of thumb, the higher the level of inventory turnover the better the inventory management. To improve the performance of inventory turnover, supplier and buyer should cooperate to reduce inventory and optimize distribution channels, adopting new inventory management strategies such as postponement and joint replenishment strategies. Comparisons cannot be made between the absolute turnover rates of different compa-

Table 2. Performance indices of buyer-supplier coordination.

\begin{tabular}{|c|c|c|c|}
\hline Type & Dimension & Indices & Note \\
\hline \multirow[t]{15}{*}{ Operational level performance } & Materials flow & Inventory turnover level & \\
\hline & & Safety stock level & \\
\hline & & On time delivery level & \\
\hline & & Lead time and purchasing tendencies & \\
\hline & & Quality of materials & \\
\hline & Cash flow & Ratio of timely clearing payment & \\
\hline & Information flow & Frequency of information exchanges & \\
\hline & & Timeliness of information transfer & * \\
\hline & & Rate of accuracy of transferred information & * \\
\hline & & Cost of communicating information & $*$ \\
\hline & Work flow & Average number of buyer/supplier conflicts per year & \\
\hline & & Agility in changing supply plans & \\
\hline & & Speed in solving feedback problems & \\
\hline & & Degree of joint participation in quality improvement & \\
\hline & & Effect of cooperation in reducing cost & \\
\hline \multirow[t]{4}{*}{ Strategic level performance } & Degree of trust & Supplier's trust in buyer & \\
\hline & & Buyer's trust in supplier & \\
\hline & Degree of satisfaction & Supplier's satisfaction with buyer & \\
\hline & & Buyer's satisfaction with supplier & \\
\hline
\end{tabular}

Table 3. Statistical results of sampling.

\begin{tabular}{lccccccccc}
\hline Sampling time & \multicolumn{2}{c}{ Questionnaire sent out } & \multicolumn{4}{c}{ Replies received } & \multicolumn{2}{c}{ Response rate } \\
& Total & Mail & Spot & Total & Mail & Spot & Effective & Total & Effective \\
\hline First & 1520 & 1420 & 100 & 89 & 40 & 49 & 80 & $5.80 \%$ & $5.2 \%$ \\
Second & 575 & 275 & 300 & 162 & 13 & 149 & 131 & $28.10 \%$ & $22.8 \%$ \\
Total & 2095 & 1695 & 400 & 251 & 53 & 198 & 211 & $11.98 \%$ & $10.0 \%$ \\
\hline
\end{tabular}


nies because they use different materials. Therefore, we used a comparison index for our analysis - the tendency of inventory turnover rate, as indicated in Table 4.

From Table 4, one can see that the performance of inventory turnover level is not very good, because the inventory turnover rate shows a "downward" and "no change" tendency (total about 70\%) that exceeds the "upward" trend (only 29.2\%). Although many market factors can influence the performance of inventory turnover, the data shown here indicates that companies would do well to increase their cooperation and coordination in inventory management.

\subsubsection{Safety stock}

Most companies need to maintain a safety stock to mitigate the impact of demand or supply uncertainties on production operations. However, safety stocks should be kept at suitable levels. In our study, we used the safety stock proportion (percentage that safety stock materials represent in the total amount of materials) and safety stock tendencies as the two coordination performance indices.

Figure 1 shows that, in the last three years, the proportion of safety stock of about half the companies was on a "downward" trend (42.4\%), 22\% showed an "upward" trend, and $35.6 \%$ of companies showed basically "no change". In other words, there is an overall downward trend of safety stock levels, which is a good sign of improvement.

Another index "safety stock proportion trend" also shows a similar pattern, with $20.9 \%$ companies showing an "upward" trend, $41.4 \%$ a "downward" trend, and $37.7 \%$ showing basically "no change".

According to inventory theory, two factors affect the safety stock level, i.e., demand deviation and supply lead

Table 4. Inventory Turnover level.

\begin{tabular}{lccc}
\hline & \multicolumn{3}{c}{ Tendency of inventory turnover rate } \\
& Downward & Upward & $\begin{array}{c}\text { Basically } \\
\text { no change }\end{array}$ \\
\hline Respondent rate & $34.4 \%$ & $29.2 \%$ & $36.4 \%$ \\
\hline
\end{tabular}

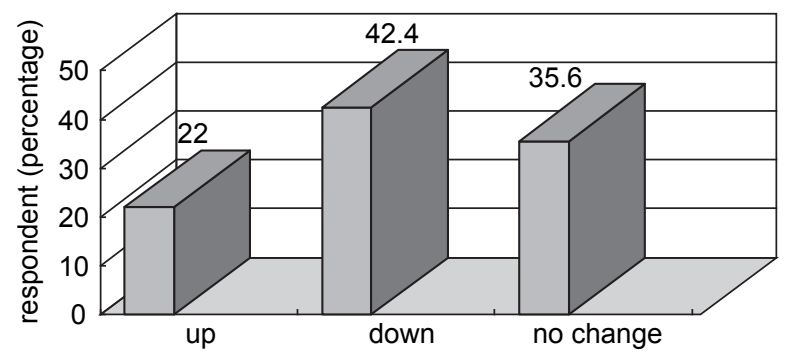

Figure 1. Safety stock proportion trends in the last three years. time. The relationship of these two factors can be formulated as:

$$
S S=z \sqrt{\bar{L} \sigma_{d}^{2}+\bar{d}^{2} \times \sigma_{L}^{2}}
$$

To reduce the safety stock, supplier and buyer should work together to shorten lead times and reduce the demand uncertainty factor. To this end, some firms and their suppliers have cooperation initiatives to improve inventory management, such as TCL (a major Chinese TV manufacturer), which has used Vendor Management Inventory (VMI) as a new inventory management technology.

\subsubsection{On time delivery}

Time is now generally recognized as the most important competitive element; hence, improving the level of on time delivery is essential for most companies. Table 5 shows our survey's findings on the on time delivery level.

Table 5 shows that delivery performance is basically satisfactory. Furthermore, the on time delivery trend (Figure 2) reveals that performance of on time delivery has improved, indicating that many Chinese companies have improved their response to market demands.

To improve their on time delivery performance, some Chinese firms have implemented the JIT philosophy in purchasing, such as Dongfeng Citroen Automobile Company (DCAC), a Sino-French joint venture in Wuhan. By establishing close relationships with several important suppliers and through JIT purchasing, DCAC has improved the timeliness of its deliveries and reduced its inventory costs.

\subsubsection{Lead times and related purchasing tendencies}

Like the index of on time delivery, lead time is also a

Table 5. On time delivery level.

\begin{tabular}{lcccc}
\hline & \multicolumn{3}{c}{ Rate of on time delivery } \\
& Below & & & Over \\
& $\mathbf{9 0 \%}$ & $\mathbf{9 0}$ to 94\% & $\mathbf{9 5}$ to 99\% & $\mathbf{9 9 \%}$ \\
\hline Respondent & $11.3 \%$ & $28.1 \%$ & $41.4 \%$ & $19.2 \%$ \\
\hline
\end{tabular}

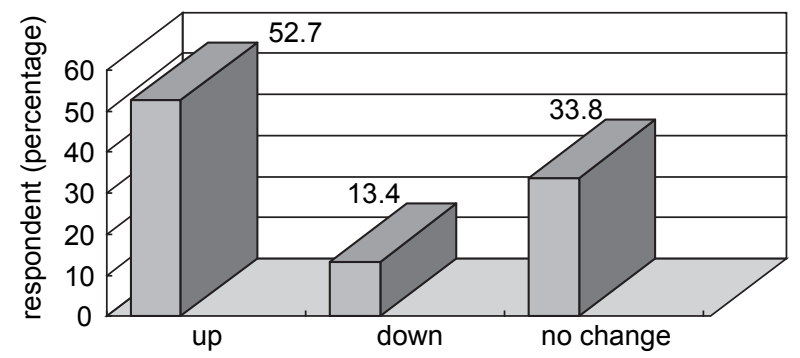

Figure 2. On time delivery trend in the last three years. 
time-based competitive element. However, absolute lead time values cannot be compared because different materials have different lead time requirements. Therefore, our analysis was based on lead time tendencies. Figure 3 illustrates the survey's findings on lead time tendencies over the last three years, indicating that more than $50 \%$ of the companies surveyed are aware of the importance of reducing purchasing lead times in order to be time-based competitive.

Longer lead times not only cause inventory buildups but also produce the "Bullwhip Effect" across supply chains; therefore, supplier and buyer should cooperate to optimize the business process, e.g., by adopting the E-purchasing mode, and improve the efficiency of their logistics systems. Dongguan Ark-Les is a Sino-foreign joint venture located in Guangdong province, China. Because the majority of materials were purchased from North America in the past, the average lead time was very long and materials inventory tied up too many funds. Today, however, the local supplier development program has not only cut down logistics costs but also shortened

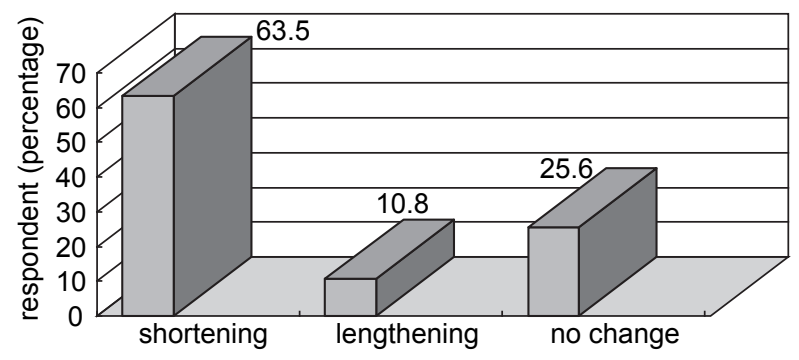

Figure 3. Lead time tendency in the last three years.

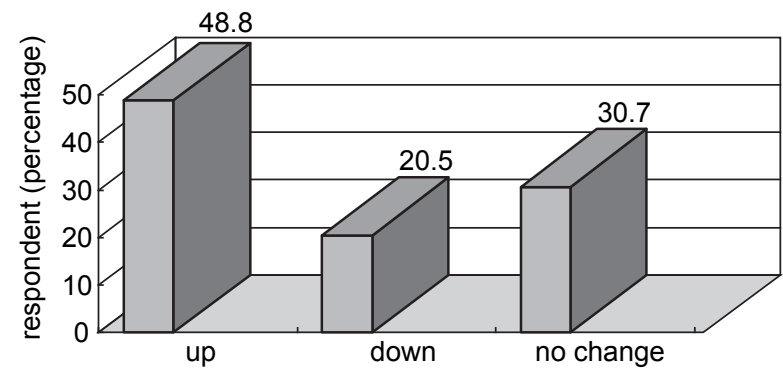

Figure 4. Average quality trends in the last three years. materials procurement lead times (from the original six weeks to two weeks).

\subsubsection{Quality of materials}

From the standpoint of supply chain management, supplier and buyer should help each other to improve quality. The quality of materials often indicates coordinated supplier/buyer strategies to improve quality. Materials quality trends in the past three years are illustrated in Figure 4.

This finding indicates that, over the last three years, a large proportion of the surveyed companies focused increasing attention on the problem of quality. In the last decade, many Chinese companies have adopted advanced management systems and methods to improve quality, including Total Quality Management (TQM), ISO 9000 systems and Six Sigma, which should help improve the quality of their materials.

\subsubsection{Cash flow coordination performance}

Although cash flow is one of the four activities in the supply chain, it has failed to attract enough attention from academics. Fewer researches have focused on cash flow performance than on materials or information flows. In our survey, we used the on time clearing payment rate as the index to measure supplier/buyer coordination performance, which is shown in Table 6 and Figure 5.

Table 6 shows that almost $70 \%$ of companies make their payments in a timely manner. Further analysis reveals that companies with different types of ownership display dissimilar cash flow coordination performance. Foreign companies show the best performance, while privately owned and state-owned companies display a relatively poorer performance.

\subsubsection{Information flow coordination per- formance}

Information flow coordination is one of the most exhaustively studied topics in supply chain research (Sahin and Robinson, 2002; Thonemann, 2002). Information sharing and communication reduce uncertainties and increase the synchronism of buyer/supplier operations.

The indices we used here to measure the performance of information coordination were: (1) frequency of in-

Table 6. Ratio of on time clearing payment.

\begin{tabular}{lcccc}
\hline & \multicolumn{4}{c}{ Timely clearing payment rate } \\
& Under 70\% & Over 80\% & Over 90\% & $\mathbf{1 0 0 \%}$ \\
\hline Total respondents & $13.9 \%$ & $18.7 \%$ & $40.7 \%$ & $26.8 \%$ \\
State-owned companies & $9.3 \%$ & $28.1 \%$ & $40.5 \%$ & $21.8 \%$ \\
Privately owned firms & $16.6 \%$ & $27.7 \%$ & $33.0 \%$ & $22.0 \%$ \\
Joint ventures & $3.7 \%$ & $12.9 \%$ & $41.7 \%$ & $41.7 \%$ \\
Foreign companies & 0 & $11.1 \%$ & $50.0 \%$ & $38.8 \%$ \\
\hline
\end{tabular}


formation communication; (2) on time of information transfers; (3) accurate rate of information transfers; and (4) cost of information communication. In our analysis we used only the index of frequency of information communication because most of the respondents could not give precise data in their response for other indices (most of them did not answer those questions).

Figure 6, which illustrates our findings on information performance, reveals that most companies communicate frequently with their partners. However, our analysis of supplier/buyer coordination strategies revealed that information was exchanged mainly by telephone, letter and fax, while the use of advanced communication technologies such as the Internet and Electronic Data Interchange (EDI) was not common. This fact suggest that to improve supplier/buyer coordination, companies would do well to adopt up-to-date IT technologies to link supply chains and speed up the exchange of information between partners.

\subsubsection{Workflow coordination performance}

The literature on supply chain management reveals that most researchers consider only three dimensions of coordination - information flow, materials flow and cash flow coordination. In this paper, we add another dimension - workflow coordination. We divide the workflow performance into five indices: (1) average annual number of buyer/supplier conflicts; (2) agility of supply plan changes; (3) speed of feedback problem solving; (4) degree of mutual participation in quality improvements; and (5) effect of coordination in reducing cost.

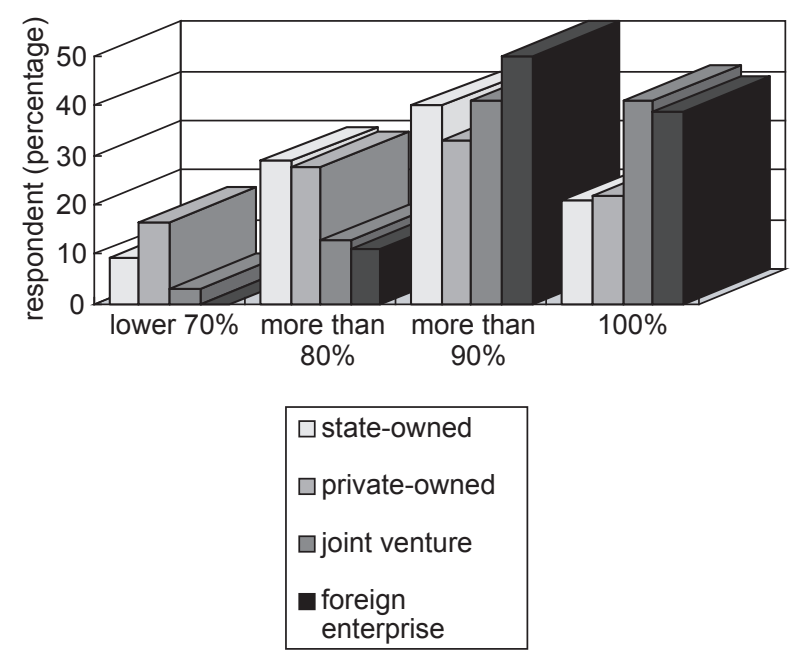

Figure 5. Ratio of timely clearing payments among different types of companies.

\subsubsection{Average annual number of buyer/ supplier conflicts}

Supplier/buyer relationships may often be rife with conflicts, particularly if the two partners have different business goals and styles. However, such conflicts can be minimized through effective buyer/supplier coordination, thus reducing avoidable waste of time and cost. We have used the average annual number of buyer/supplier conflicts to measure this performance, which is shown in Table 7.

Table 7 shows the absolute number of conflicts. However, since different companies have different scales and modes of operation, these figures cannot be used for purposes of comparison. Our analysis of the improvement level of this index is based on the annual tendency for conflicts, shown in Figure 7.

Figure 7 indicates that almost $50 \%$ of the surveyed companies reported a declining number of conflicts over the last three years, indicating that many of them have improved their workflow by reducing the number of conflicts.

\subsubsection{Agility of changing supply plan}

Market demand changes constantly. If the supplier can make rapid adjustments to his supply plan to meet changing demands, losses incurred by overstocking or stock-

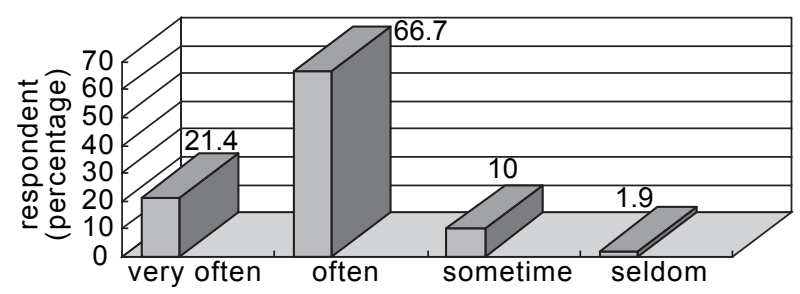

Figure 6. Frequency of information exchanges.

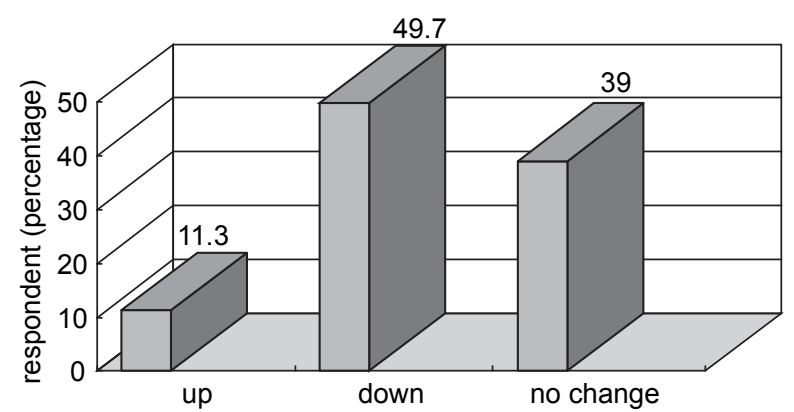

Figure 7. Tendency of the number of conflicts in the last three years.

Table 7. Average number of conflict affair between buyer and supplier each year.

\begin{tabular}{lcccc}
\hline & \multicolumn{4}{c}{ Average annual number of buyer/supplier conflicts } \\
& Over 10 & $\mathbf{6}$ to 10 & $\mathbf{1}$ to 5 & None \\
\hline Respondent & $18.8 \%$ & $16.8 \%$ & $43.6 \%$ & $20.8 \%$ \\
\hline
\end{tabular}


outs can be reduced to a minimum. Therefore, agility in responding to supply plan changes is a very important performance factor in the workflow. Figure 8 shows that most of the surveyed companies respond rapidly to changing supply plans, i.e., in China, many suppliers are aware of the importance of cooperating with the buyer, enabling the latter to respond quickly to market demands.

\subsubsection{Speed of feedback problem solving}

In the course of coordinated supplier/buyer operations, suppliers should handle complaints from buyers speedily and address the buyer's complaints in a timely manner. Thus, the speed with which the supplier takes care of the buyer complaints is an important indicator of the supplier's coordination ability. This performance is illustrated in Figure 9.

As can be seen, many suppliers can respond quickly to solve the buyer's feedback problem. This situation is similar to the "agility in responding to supply plan changes", i.e., the supplier usually responds quickly to the buyer's demands. However, during our interviews at manufacturers, some mangers stated that many of their suppliers do not take proactive steps in helping them solve problems. Instead, those suppliers are reactive, attempting to solve problems only after they arise.

\subsubsection{Degree of joint participation in quality improvements}

It is a well known fact that Japanese companies work in close cooperation and coordination with their suppliers on issues of quality management, and that they often take

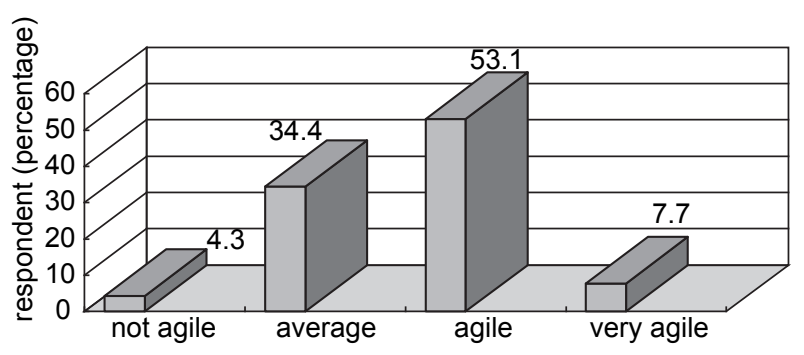

Figure 8. Agility of supply plan changes. consistent actions with suppliers in implementing quality improvements. Today, an increasing number of companies in China are learning from the Japanese how to increase their cooperation and coordination with suppliers in managing quality. Table 8 reveals that many buyers and their suppliers have participated jointly in quality improvements, particularly several Sino-Japanese joint ventures. For example, Honda Guangzhou, the largest automobile manufacturer in southern China, has gone a long way toward cooperating with its suppliers in quality management issues. Most of Honda's suppliers are proud to supply to Honda Guangzhou.

\subsubsection{Effect of coordination in reducing cost}

It is well known that the basic law of business operations is Profit is equal income minus cost. Based on this law, the goal of supply chain management is to increase customer service and reduce supply chain operating costs. Therefore, the effect of coordination in reducing cost is a very important performance indicator in supplier/buyer coordination.

Table 9 shows that the effect of supplier/buyer coordination in reducing cost is unremarkable. Why is this so? An in-depth analysis of supplier/buyer coordination strategies revealed that, although many companies engage in coordinated activities with their partners, these activities are limited mostly to short-term and operational, rather than long-term and strategic activities. This suggests that they prioritize transaction cost reductions over strategic purchasing cost reductions.

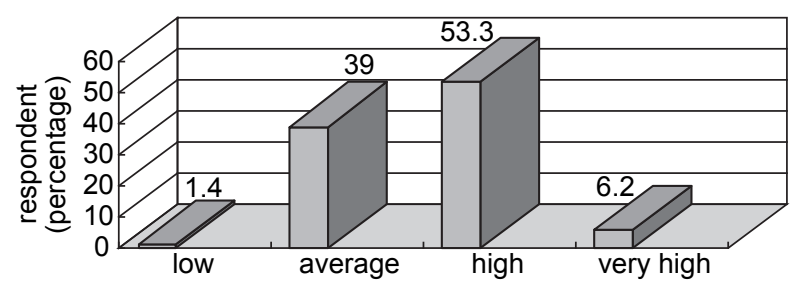

Figure 9. Speed in solving feedback problems.

Table 8. Degree of joint participation in quality improvement.

\begin{tabular}{lccccc}
\hline & \multicolumn{4}{c}{ Joint participation in quality improvements } & \\
& Never & Seldom & Sometime & Often & Always \\
\hline Respondent & $1.0 \%$ & $3.9 \%$ & $19.9 \%$ & $55.3 \%$ & $19.9 \%$ \\
\hline
\end{tabular}

Table 9. Effect of coordination in reducing cost.

\begin{tabular}{lcccc}
\hline & \multicolumn{4}{c}{ Effect of coordination in reducing costs } \\
& No effect & Slight effect & Strong effect & Very strong effect \\
\hline Respondent & $7.2 \%$ & $44.7 \%$ & $41.3 \%$ & $6.7 \%$ \\
\hline
\end{tabular}




\subsection{Performance of strategic coordination}

In the above section, we reported our findings regarding the operational performance of supplier/buyer coordination. In this section, we will discuss performance at a strategic level. Our survey encompasses two indices for the dimension of strategic performance: degree of trust and degree of satisfaction.

\subsubsection{Degree of trust}

Trust is the cornerstone of market economies. The greater the degree of mutual trust, the closer the supplier/ buyer relationship. To evaluate the difference between buyer and supplier in terms of degree of trust, we use two indices, i.e., the supplier's trust in the buyer and the buyer's trust in the supplier. Table 10 shows that most suppliers' and buyers' mutual trust is intermediate or high; this finding corresponds to $80 \%$ to $90 \%$ of the surveyed companies. However, only a few companies stated their trust in their partner was very high. Our survey, however, revealed that the degree of trust between supplier and buyer is asymmetric. The supplier's degree of trust in the buyer was found to be higher than the buyer's degree of trust in the supplier.

\subsubsection{Degree of satisfaction}

In competitive markets, many companies are familiar with the strategy of customer satisfaction (CS) to upgrade company identification $(\mathrm{CI})$. We use the degree of satisfaction here as another important index of strategic performance of supplier/buyer coordination. Table11 indicates that the degree of mutual satisfaction is distributed fairly equally between supplier and buyer, and that the overall degree of satisfaction of both suppliers and buyers is on the level of intermediate or satisfied in more than $90 \%$ of the surveyed companies. Only $4.7 \%$ of suppliers and $1.9 \%$ of buyers consider they are highly satisfied. Similarly to the degree of trust, we found the degree of satisfaction between supplier and buyer is asymmetric. The supplier's degree of satisfaction with the buyer is higher than vice-versa.

\section{Conclusions and implications for ma- nagement}

China's economy has been growing at a tremendous rate for over two decades. But what about the status of supply chain management in China? How should western firms proceed with their strategy in China? Based on this empirical investigation into the supplier/buyer coordination performance of Chinese companies, a number of conclusions and managerial implications can be drawn.

\subsection{Conclusions}

1. Based on a review of the literature and on a survey, this paper indicated four dimensions of supplier/buyer coordination performance based on four supply chain flows, thus differing from the traditional standpoint which considers only three flows. Detailed indices for measuring supplier/buyer coordination performance were described;

2. Overall, most Chinese companies are aware of the need to increase their cooperation and coordination with partners in their supply chain, but coordinated activities are limited mostly to a short-term operational level and do not usually extend to a long-term strategic level. Many enterprises have not yet formed close cooperative relationships with partners; and

3. The use of supply chain management has wrought profound changes in the supplier/buyer relationships between Chinese companies. According to the evolution of the law of supplier/buyer relationships (Da Villa and Panizzolo, 1996), this relationship in most Chinese companies is still in the logistics phase. Only a few companies have reached the partnership phase of their relations (see Figure 10).

\subsection{Managerial implications}

Based on these conclusions, we put forward some suggestions regarding managerial implications for Chinese companies and foreign enterprises in China.

Table 10. Mutual trust between buyer and supplier.

\begin{tabular}{lcccc}
\hline & \multicolumn{4}{c}{ Degree of trust between buyer and supplier } \\
& Low & Intermediate & High & Very high \\
\hline Supplier's degree of trust in buyer & $1.4 \%$ & $24.2 \%$ & $60.2 \%$ & $14.2 \%$ \\
Buyer's degree of trust in supplier & $3.3 \%$ & $36.5 \%$ & $58.8 \%$ & $1.4 \%$ \\
\hline
\end{tabular}

Table 11. Degree of satisfaction between buyer and supplier.

\begin{tabular}{lcccc}
\hline & \multicolumn{3}{c}{ Degree of Satisfaction between buyer and supplier } \\
& Dissatisfied & Intermediate & Satisfied & Very satisfied \\
\hline Supplier's degree of satisfaction with buyer & $0.9 \%$ & $30.3 \%$ & $64.0 \%$ & $4.7 \%$ \\
Buyer's degree of satisfaction with supplier & $2.4 \%$ & $34.3 \%$ & $61.4 \%$ & $1.9 \%$ \\
\hline
\end{tabular}




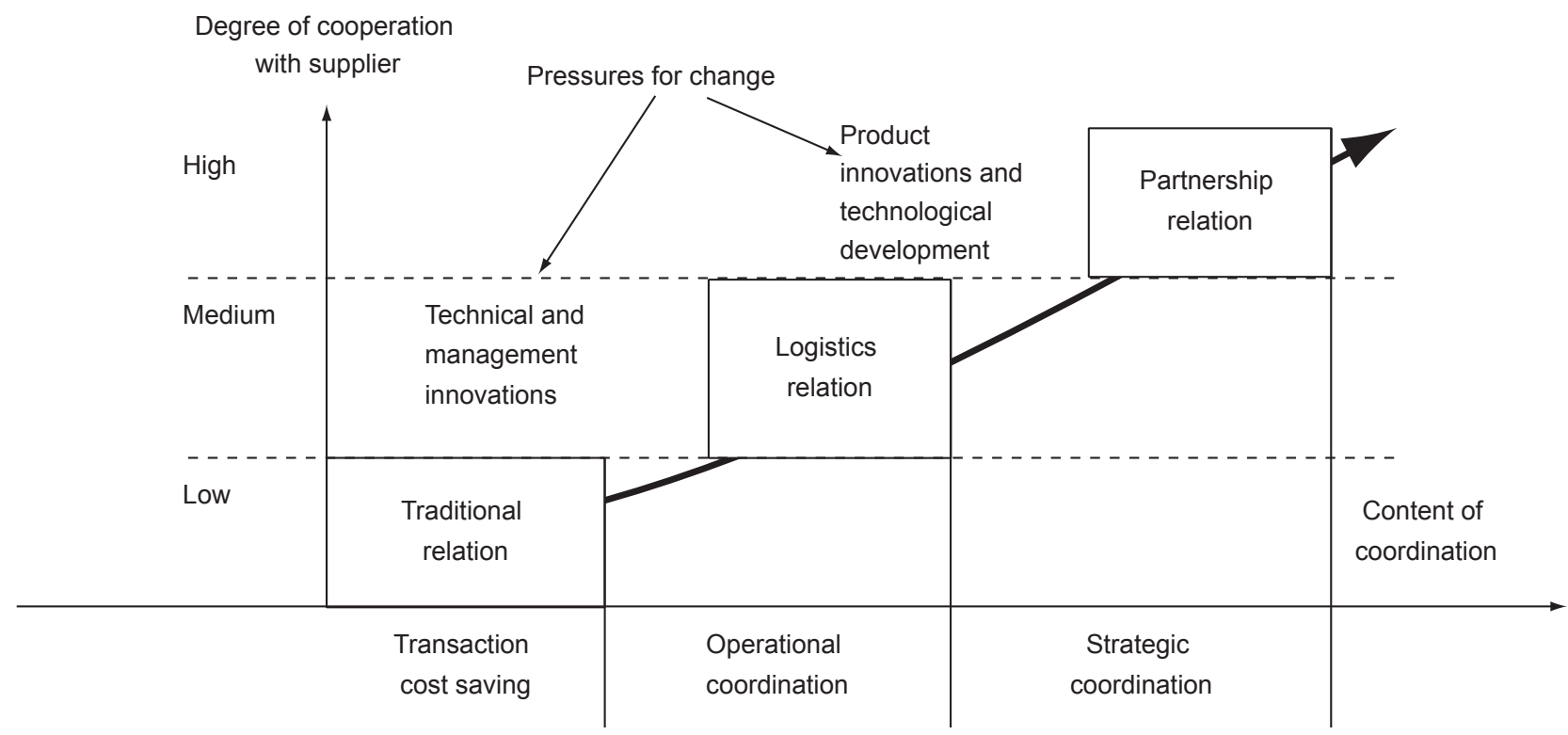

Figure 10. Evolution of supplier/buyer relations and coordination content.

1. Improve the performance of strategic cooperation and coordination, particularly the dimension of mutual trust between supplier and buyer;

2. Build a basic infrastructure for improving supplier/ buyer coordination, particularly Internet-based communication and an information exchange infrastructure; and

3. State-owned and private companies should emulate foreign and Sino-foreign joint ventures, with a view to improving their supplier/buyer coordination performance, particularly their cash flow coordination.

\section{Acknowledgements}

This research was funded by the National Natural Science Foundation of the People's Republic of China (70271023) and by the China National High Technology Research and Development Program (863) (2001AA414230).

\section{References}

AGARWAL, A.; SHANKAR, R. Analyzing alternatives for improvement in supply chain performance. Work study, v. 51, n. 1, p. 32-37. 2002.

BEAMON, B. M. Measuring supply chain performance. International Journal of Operations \& Production Management, v. 19, n. 3, p. 275-292, 1999.

CHAN, F. T. S.; QI, H. J. A fuzzy basis channel-spanning performance measurement method for supply chain management. Proc Instn Mech Engrs part B: J. Engineering Management, n. 215, p. 1155-1167, 2002.

FABRIZIO, S.; CIPRIANO, F.; MANUS, R.; THOMAS, Y. C. Supply chain interactions and time-related performances. International Journal of Operations \& Production Management, v. 21, n. 4, p. 461-475, 2001.

GRAHAM, T. S.; DOUGHERTY, W. N. The long term strategic impact of purchasing partnerships. International Journal of Purchasing and Materials Management, v. 30, n. 4, p. 13-18, 1994.

GUNASEKARAN, A.; PATEL, C.; TIRTIROUGLU E. Per- formance measures and metrics in a supply chain environment. International Journal of Operations \& Production Management, v. 21,n. 1-2, p. 71-87, 2001.

MALONI, M. J.; BENTON, W. C. Supply chain partnerships: opportunities for operations research. European Journal of Operational Research, v. 101, n. 3, p. 419-429, 1997.

MASON-JONES, R.; ToWILL, D.R. Total Cycle Time Compression and the agile supply chain. International Journal of Production Economics, v. 62, n. 1, p. 61-73, 1999.

RAMDAS, K.; SPEKMAN, R. E. Chain or shackles: understanding what drives supply chain performance. Interfaces, v. 30, n. 4, p. 3-21, 2000.

SAHIN, F.; ROBINSON, E. P. Flow coordination and information sharing in supply chains: review, implications, and directions for future research. Decision Sciences, v. 33 , n. 4, p. 505-536, 2002.

THOMAS, D. J.; GRIFFIN, P. M. Coordinated Supply chain management. European Journal of Operational 
Research, v. 94, n. 1, p. 1-5, 1996.

THONEMANN, U. W. Improving supply chain performance by sharing advance demand information. European Journal of Operational Research, v. 142, n. 1, p. 81107, 2002.

TONI, A. D., NISSIMBENI G.; TONCHIA S. New trends in supply environment. Logistics Information Management. v. 7, n. 4, p. 41-55, 1994.
VAN HOEK, R. I.; HARRISON, A.; CHRISTOPHER, M. Measuring agile capabilities in the supply chain. International Journal of Operations \& Production Management, v. 21,n. 1-2, p. 126-147, 2001.

VILLA, F. D.; PANIZZOLO, R. Buyer-subcontractor relationships in the Italian clothing industry. International Journal of Operations \& Production management, v. 16, n. 7, p. 38-61, 1996.

\section{INVESTIGAÇÃO SOBRE O DESEMPENHO DA COORDENAÇÃO CLIENTE/FORNECEDOR EM EMPRESAS CHINESAS}

\section{Resumo}

Este artigo discute o desempenho da coordenação entre clientelfornecedor em cadeias de suprimento da China com base em dados de uma pesqquisa de avaliação (survey). Os resultados indicam que a rápida expansão da economia fez com que um número crescente de empresas chinesas passasse a dar mais atenção para a importância da cooperação e coordenação entre os parceiros na gestão da cadeia de suprimentos. Embora entrega, qualidade e responsividade apresentem uma tendência de melhora o mesmo não é observado para compartilhamento da informação e esforços conjuntos para redução de custos e inventários. Portanto, muitas empresas ainda precisam estabelecer relacionamentos cooperatives com os seus parceiros. Este estudo pode ser útil tanto para empresas chinesas quanto para empresas estrangeiras, servindo de base para o desenvolvimento de novas estratégias para a gestão de cadeias de suprimentos numa economia global em mudança.

Palavras-chave: relacionamento clientelfornecedor, coordenação, cadeia de suprimentos ágil. 